\title{
The Quality of the Water from the Aquatic Ecosystem, Carja, through the Biological Indexes
}

\author{
Adina POPESCU*, Daniela Cristina IBANESCU \\ University „Dunarea de Jos” of Galati, Faculty of Food Science and Engineering, Department of \\ Aquaculture, Environmental Sciences and Cadastre, Domneasca Street, 47, Galati 800087 Romania; \\ *corresponding author, e-mail: adina.popescu@ugal.ro
}

Bulletin UASVM series Agriculture 73(1)/2016

Print ISSN 1843-5246; Electronic ISSN 1843-5386

DOI 10.15835/buasvmcn-agr: 12023

\begin{abstract}
The objective of this paper is to evaluate organic pollution in the basin growth cyprinids (Balta Mare) of farm Carja 1 Vaslui county, it was based on the two indices, namely algal genus pollution index and saprobes' index. Algae as a component of the aquatic ecosystem is an indicator of water quality, which is determined by the component species and of their diversity. Total 18 genera and 29 species have been indentified, among these 13 species belonged to Cholorophyceae, 5 species to Cyanophyceae, 5 species to Bacillariophyceae, 5 species Euglenophyceae and 1 species to Dinophyceae. Have also been analyzed and the main physic-chemical parameters as follows temperature, $\mathrm{pH}$, oxygen and the other parameters (nutrients viz. nitrogen and phosphorous). The Values of physic-chemical parameters show that water belongs to class III of quality, according to Order $161 / 2006$. Two biological indices, viz. algal genus pollution index and saprobes' index, were adopted to classify the water quality in the Balta Mare in comparison with the measured physicochemical water quality. The total score of Algal Genus Pollution Index of station CI, CII, CIII, CIV, CV, CA/E were 15, 15, 17, 8, 7 and 9 respectively. Water quality ecosystem investigated is assigned to the $\beta$ mesosaprobic subarea, prevailing the $\beta$-mesosaprobic species, class III of quality and moderately polluted water.
\end{abstract}

Keywords: algae, water, algal genus pollution index, saprobic index

\section{INTRODUCTION}

Phytoplanktons are the primary producers in pelagic food chain and they need nutrients. Algae are known as reliable biological indicators of water pollution (Palmer, 1980). Algae have been pointed out as a useful tool for estimation of the environmental impact on the aquatic ecosystem due to its quick response to changes in the environmental condition thus enabling a quick assessment of water quality (Zeng et al., 2006; Pongsarun et al., 2007).

Biological indicators of water pollution are saprobes; organisms have adapted to live in polluted waters. Thus, the level of water pollution can be determined by the presence and the quantity of saprobes. In this respect, it was developed a saprobes system by Kolkwitz and Marsson (1908, 1909), Liebmann (1962) making a broad review of its, system that was used and developed by many other researchers. The saprobic level can represent an important indicator for the water quality.

\section{AIMS AND OBJECTIVES}

In present investigation algal communities which are used as indicator of aquatic pollution.

\section{MATERIALS AND METHODS}

The different genera of planktonic algae were observant along with the physic-chemical parameters like DO, BOD, nutrients viz. nitrogen (nitrate, nitrite, ammonia) and phosphorous in May 2011. The physic-chemical monitoring and the plankton sampling was done in Balta Mare of the fish farm, Carja 1, Vaslui county, from 6 stations established with the help of a Garmin GPS 72-type 
navigation system, numbered C1-C6, CA-E (feeding and evacuation). The Carja 1 is an anthropogenic aquatic ecosystem from Moldova SE supply Prut River.

Two biological indices were calculated as follows:

1) The pollution status of the sampling stations of Balta Mare was determined based on algal genus pollution index (Palmer, 1969). In making a microscopic analysis of a sample, all of the 20 algae observed were recorded. The index factors of the algae present were then totalled. Algal genus pollution index, as shown in Table 1.

2) Saprobic index (S). In present, in Romania, the biological method used for the phytoplankton analysis of water bodies is the PantleBuck method (1955), in which the authors make a classification of the degree of water contamination with biodegradable organic matter by the saprobes system.

$\mathrm{S}=\Sigma\left(\mathrm{s}^{*}\right.$ hi) $/ \sum$ (hi), Where:

$\mathrm{s}=$ numerical value characteristic belonging to the saprobic area (these values are listed in the Order 161/2006.)

$\mathrm{h}=$ absolute numerical abundance of individuals of a particular taxon

$\mathrm{I}=$ taxon

\section{RESULTS AND DISCUSSION \\ Environmental Variables}

The results obtained from analyzes have been interpreted both in point of view corresponding water quality of species cyprinids ecophysiological requirements and in terms of class III limitations,

Tab. 1. Algal genus pollution index (Palmer, 1969)

\begin{tabular}{cccc}
\hline Genus & Pollution index & Genus & Pollution index \\
\hline Anacystis & 1 & Micractinium & 1 \\
\hline Ankistrodesmus & 2 & Navicula & 3 \\
\hline Chlamydomonas & 4 & Nitzschia & 3 \\
\hline Chlorella & 3 & Oscillatoria & 5 \\
\hline Closterium & 1 & Pandorina & 1 \\
\hline Cyclotella & 1 & Phacus & 2 \\
\hline Euglena & 5 & Phormidium & 1 \\
\hline Gomphonema & 1 & Scenedesmus & 4 \\
\hline Lepocinclis & 1 & Stigeoclonium & 2 \\
\hline Melosira & 1 & Synedra & 2 \\
\hline
\end{tabular}

Tab. 2. Physico-chemical parameters

\begin{tabular}{ccccccccc}
\hline Station & $\begin{array}{c}\mathrm{T} \\
{ }^{\circ} \mathrm{C}\end{array}$ & $\mathrm{pH}$ & $\begin{array}{c}\mathrm{DO} \\
\mathrm{mg} / \mathrm{l}\end{array}$ & $\begin{array}{c}\mathrm{N}\left(\mathrm{NH}_{4}\right) \\
\mathrm{mg} / \mathrm{l}\end{array}$ & $\begin{array}{c}\mathrm{N}\left(\mathrm{NO}_{2}\right) \\
\mathrm{mg} / \mathrm{l}\end{array}$ & $\begin{array}{c}\mathrm{N}\left(\mathrm{NO}_{3}\right) \\
\mathrm{mg} / \mathrm{l}\end{array}$ & $\begin{array}{c}\mathrm{CBO}_{5} \\
\mathrm{mg} \mathrm{02/l}\end{array}$ & $\begin{array}{c}\mathrm{P}\left(\mathrm{PO}_{4}\right) \\
\mathrm{mg} / \mathrm{l}\end{array}$ \\
\hline $\mathrm{C} 1$ & 18,90 & 8,53 & 9,15 & 0,24 & 0,01 & 2,30 & 7,72 & 0,06 \\
\hline $\mathrm{C} 2$ & 19,10 & 8,69 & 9,45 & 0,22 & 0,01 & 2,33 & 7,54 & 0,06 \\
\hline $\mathrm{C} 3$ & 19,60 & 8,67 & 9,82 & 0,19 & 0,01 & 1,85 & 7,27 & 0,06 \\
\hline $\mathrm{C} 4$ & 19,20 & 8,66 & 9,33 & 0,17 & 0,01 & 1,14 & 7,24 & 0,05 \\
\hline $\mathrm{C} 5$ & 19,70 & 8,69 & 8,22 & 0,14 & 0,02 & 2,30 & 7,36 & 0,06 \\
\hline $\mathrm{C} 6 \mathrm{~A} / \mathrm{E}$ & 18,90 & 8,72 & 9,15 & 0,11 & 0,02 & 4,55 & 7,47 & 0,03 \\
\hline
\end{tabular}


Tab. 3. Saprobic Index value on stations

\begin{tabular}{ccccccc}
\hline Station & C1 & C2 & C3 & C4 & C5 & C6 (A/E) \\
\hline Saprobic Index (S) & 1,99 & 2,33 & 2,63 & 2,12 & 2,18 & 2,10 \\
\hline
\end{tabular}

Tab. 4. Pollution tolerant general

\begin{tabular}{cccccccccc}
\hline Genera & Algal Group & Pollution index & C1 & C2 & C3 & C4 & C5 & C6 (A/E) \\
\hline Anabena & Cyanophyceae & 1 & + & + & - & - & - & - \\
\hline Oscilatoria & Cyanophyceae & 4 & - & - & - & - & - & + \\
\hline Euglena & Euglenophyceae & 5 & + & + & + & + & - & - \\
\hline Phacus & Euglenophyceae & 2 & + & + & + & + & - & - \\
\hline Navicula & Bacillariophyceae & 3 & + & + & + & - & - & - \\
\hline Pinularia & Bacillariophyceae & 1 & - & + & - & - & - & - \\
\hline Synedra & Bacillariophyceae & 2 & - & + & + & - & + & - \\
\hline Nitzschia & Bacillariophyceae & 3 & + & - & - & - & - & - \\
\hline Pediastrum & Cholorophyceae & 1 & + & + & + & + & + & + \\
\hline Scenedesmus & Cholorophyceae & 4 & - & - & + & - & + & + \\
\hline & & Total score & 15 & 15 & 17 & 8 & 7 & 9 \\
\hline
\end{tabular}

the fish breeding water use, according to Order 161/2006 (table 2).

\section{Taxonomic and Saprobity}

Total 18 genera and 29 species have been indentified, among these 13 species belonged to Cholorophyceae, 5 species to Cyanophyceae, 5 species to Bacillariophyceae, 5 species Euglenophyceae and 1 species to Dinophyceae. In growth basin for the cyprinids consumer in Balta Mare, from 29 species identified in May -2011, 24 species are indicators of water quality, most of which are o-oligosaprobic organism $(0.61 \%)$, o- $\beta$-oligo-mesosaprobic $(6.67 \%) \beta$-mesosaprobic (71.61\%), $\beta$ - $\alpha$ mesosaprobic (6.67\%), $\alpha$-mesosaprobic $(11.52 \%)$ and $p-\alpha$ polysaprobic $(3.94 \%)$. The Phytoplankton saprobic index have values between 1.99 and 2.63, according to Norm $161 / 2006$ which indicates that the water belong to the class III of quality, a moderate ecological status and a mesotrophic level (table 3 ).

\section{Indices API}

Algal genus pollution index: According to the three quality classes defined for algal genus pollution index by Palmer and Adams, the water quality the Balta Mare is classified as clean water
(C4, C5 and CA/E) and moderately polluted water (C1, C2 and C3). The minimum value was recorded in C5 (table 4), partially due to the reduction in the number of algal species.

\section{CONCLUSION}

According to the classes defined for algal pollution index by Palmer, the water quality in the Balta Mare is classified as moderately polluted water. By saprobic index, the water quality in the Balta Mare ranged between 1.99-2.63, which classified into class III (moderate ecological status). The Values of physic-chemical parameters show that water belongs to class III of quality, according to Order 161/2006. In conclusion, maintaining water quality observed in the spread admissible supported by crop species.

\section{REFERENCES}

1. Kolkwitz R and Marsson M (1909). Ökologie der tierischen Saprobien. (Ecology of the animal saprobien). Int. Rev. ges. Hydrobiol. Hydrogr., 2, 126-152.

2. Liebmann H (1962). Handbuch der Frischwasser- und Abwasser-Biologie. (Handbook of the biology of fresh water and waste water). Verlag R. Oldenbourg, München. 
3. Malacea I (1969). Biologia apelor impurificate; bazele biologice ale protectiei apelor, Editura Academiei Republicii Socialiste Romania, Bucuresti.

4. Ordinul 161/2006, Ministerul Mediului şi Gospodăririi Apelor, Monitorul Oficial nr. 511 din 13 iunie 2006.

5. Palmer CM (1980). Algae \& water pollution. Castle House Publishers Ltd. England
6. Pongsarun J, Somporn C, Siripen T (2007). Biological indices for classification of water quality around Mae Moh power plant, Thailand. Maejo International - Journal of science and technology. ISSN 1905-7873.

7. Zeng H, Song L, Yu Z, Chen H (2006). Distribuyion of phytoplankton in the Three-Gorge reservoir during rainy and dry seasons. Sci. Total Environ. 236, 999-1009. 